\title{
ARGUMENT ABOUT CORRUPTION IN INTERNATIONAL ARBITRATION: ICSID CASE LAW
}

\author{
АРГУМЕНТ ПРО КОРУПЦІЮ В МІЖНАРОДНОМУ АРБІТРАЖІ: \\ ПРЕЦЕДЕНТНЕ ПРАВО МЦУІС
}

\author{
Kolosovska D.V., Student of the Economic Law Faculty
} Yaroslav Mudryi National Law University

The article analyses possible ways of combating corruption in investment relations in international arbitrations, using the International Centre for Settlement of Investment Disputes (ICSID) arbitration practice as an example. Corruption is a problem (especially relevant for Ukraine), which penetrates into most fields of social and legal relations and has a destructive effect on them. Investment relations, which are one of the most important in modern world, are also often exposed to corruption risks, whether during the conclusion of an investment agreement or already at the stage of its implementation. There are often situations when the issue of possible corruption arises directly during the consideration of an investment dispute in arbitration. The correctness of the arbitral award, as well as the degree of protection of the rights and legitimate interests of the parties depends on the correct resolution of such issues. In addition, the presence of good practice in this area will be useful to improve both international and national anti-corruption legislation.

Despite the obvious importance of this problem, there is currently no consensus on issues such as, for example, the burden and standard of proof, the liability of the parties, the consequences for the parties if the fact of corruption is proved, and so on. In the article, the author analyses the possible ways of detecting corruption during the arbitration, gives examples of indicators that may cause suspicion by the arbitrator, as well as the most common standards of proof, which are currently known and used by investment arbitrations in different circumstances. In addition, the author points out the possible role of the corruption argument in arbitration.

The author analyses the above-mentioned issues using examples from the practice of one of the most reliable and reputable arbitration bodies in the world - ICSID. Using practical examples of arbitration proceedings, the author draws attention to various approaches to proving the fact of corruption, the circumstances that influenced the decision of the arbitrators, the principles of law and doctrine that can be applied, as well as the consequences of revealing the fact of corruption for the parties to the case.

Key words: corruption, investment, international investment arbitration, liability of parties, burden of proof, standard of proof.

У статті розглянуті окремі засоби протидії корупції у діяльності міжнародних арбітражів на прикладі Міжнародного центру з урегулювання інвестиційних спорів (МЦУІС), проаналізовано досвід та ефективність їх запровадження. Корупція - явище, що не оминає жодної сфери суспільних відносин, і наша держава є однією з найбільш уражених негативними наслідками корупційних схем, у тому числі в системі здійснення правосуддя та господарській діяльності. Інвестиційні відносини, які є одними з найважливіших у сучасному світі, також часто піддаються корупційним ризикам як під час укладення інвестиційної угоди, так і на стадії її реалізації. Нерідко трапляються ситуації, коли питання можливої корупції виникає безпосередньо під час розгляду інвестиційного спору в арбітражі. Від правильності вирішення таких питань залежить справедливість арбітражного рішення, а також ступінь захисту прав та законних інтересів сторін. Крім того, наявність належної практики у цій галузі сприятиме удосконаленню як міжнародного, так і національного антикорупційного законодавства.

Незважаючи на очевидну актуальність цієї проблеми, на поточний момент відсутня єдина думка з таких питань, як наприклад тягар і стандарт доказування, розподіл відповідальності сторін, наслідки для сторін, якщо факт корупції буде доведений, та ін. У статті автор аналізує можливі способи виявлення корупції під час арбітражу, наводить приклади показників, які можуть викликати підозру у арбітра, а також найпоширеніші стандарти доказування, які нині відомі та використовуються інвестиційними арбітражами за різних обставин. Крім того, автор вказує на можливу роль аргументу щодо корупції в арбітражі.

Зазначені вище питання проаналізовано, спираючись на практику одного з найвідоміших арбітражних органів у світі - МЦУІС, що завжди мав високу репутацію та викликав довіру у міжнародних ділових колах. Використовуючи практичні приклади арбітражного розгляду, автор звертає увагу на різні підходи до доказування фракту корупції, обставини, що вплинули на рішення арбітрів, принципи права та доктрини, які можуть бути застосовані, а також наслідки виявлення факту корупція для сторін у справі.

Ключові слова: корупція, інвестиції, міжнародний інвестиційний арбітраж, відповідальність сторін, тягар доказування, стандарт доказування.

There is no doubt that corruption is a serious global problem. Corruption is an illegal activity that enhances criminal manifestations in society, undermines positive economic development, stimulating the shadow economy. Most countries put a lot of efforts into the fight against corruption, however, despite this, the above-mentioned problem remains relevant for a long time.

At the moment, when Ukraine is slowly but surely advancing towards European integration, the importance of foreign investment for its economy can hardly be overestimated. The European Commissioner for European Neighborhood Policy and Enlargement, Oliver Warghei, at a meeting of the Ukraine-EU Association Council in Brussels in January 2020, called the main conditions for increasing investment in the Ukrainian economy, namely the rule of law, the business environment and the eradication of corruption in it. Yes, unfortunately, the high level of corruption in the country discourages foreign investors, while in our country the situation is aggravated by the fact that the level of trust in the judiciary is far from satisfactory. However, a study of the practice of ICSID, which is one of the most authoritative and reliable investment arbitrations in the world, shows that the problem of corruption in concluding and executing investment agreements is relevant not only for Ukraine, but also for many countries of the world, and currently arbitration bodies only on the way to developing an effective mean to combat this phenomenon.

In their writings, such Ukrainian scientists drew attention to this question as O.V. Garagonich, V.V.Kafarsky, V.V.Komarov, S.O.Kravtsov, V.V.Kudryavtseva, O.M. Pasenyuk, D.M. Prytyka, G.S. Stefanishin, M.G. Sudorgin, O.V. Shapovalova, and others. Among foreign scientists, this question was studied by Gemma Aiolfi, Bruno Cova, Yves Fortier, Emmanuel Gaillard, Paul Gully-Hart, Joachim Knoll, Richard Kreindler, Carolyn B. Lamm, Stephan Wilske and others.

Since 2006, when an arbitral award was made in the World Duty Free v. Kenya case [1], it has been recognized that corruption, regardless of whether it is proven or not, should be taken into account in arbitration proceedings. In this dispute, the fact of bribery was recognized by the plaintiff, who in his testimony stated that he had received a concession agreement as a result of giving a bribe in the amount of $\$ 2$ million. The plaintiff claimed that he left a briefcase with money against 
the wall during a meeting with the President of Kenya, and when he picked up the briefcase after the meeting, the money was replaced by ears of corn. Kenya appealed to the court to dismiss the claim. The ICSID requested additional evidence and, as a result, ruled that the contract is null and void in the absence of legal grounds and the plaintiff's claim is rejected on the basis of non-compliance with the procedure. That was the first rejection of the lawsuit in ICSID on the basis of jurisdiction.

In this article we set a goal to highlight the issues that arise during the review of arguments about corruption in investment arbitration using the example of the International Centre for Settlement of Investment Dispute (hereinafter-ICSID). ICSID is one of the autonomous international institutions, which, along with the International Finance Corporation and the Multilateral Investment Guarantee Agency and the World Bank itself, is part of the World Bank Group, which is a specialized agency of the United Nations. As an investment arbitration, ICSID specializes in disputes between foreign investors and the states in which they invested, on the basis of international bilateral investment agreements on the promotion and mutual protection of investments, in which the states have chosen a list of arbitration institutions to which the investor can apply.

ICSID is one of the most experienced and authoritative institutions for resolving investment disputes of ICSID along with the Arbitration Institute of the Stockholm Chamber of Commerce (SCC) and the International Arbitration Court of the International Chamber of Commerce (ICC), which are also often indicated in bilateral investment agreements.

First of all, what is meant by the "argument about corruption"? In ICSID practice, the argument about corruption refers to a statement by the investment company about the fact of extortion by the government officials of the respondent state, or the fact of giving them a bribe. The issue of corruption may also arise on the initiative of the arbitrators, if they have reasonable suspicions.

There is no doubt that the arbitral awards must be lawful and enforceable, which means that the arbitrators must take into account the arguments about corruption. Based on this, in the event of issues related to corruption, the arbitrators face a rather difficult task. First of all, the difficulty is caused by the lack of a single standard of proof in international arbitration. The most common at the moment is an approach based on a universally recognized international standard: each party must prove the facts to which it refers. This principle is widely applied in national and international legal proceedings, as well as in investment and commercial arbitration.

It should be noted that the views of scientists on this issue vary significantly. The issue of corruption in the international arbitration as a whole is quite controversial, because almost all of its aspects are ambiguous and can be evaluated in different ways. However, it seems possible to highlight the main debatable issues, namely the burden of proof (which of the parties bears), the consequences for the parties if the fact of corruption is proved, as well as the liability of the parties.

As already mentioned, there is no single standard of proof. Turning to the legal basis, we note that neither the ICSID Convention [2] nor the ICSID Arbitration Rules [3] provide any specific provision on the standard of evidence. Rather, both of these documents provide the courts with the right to set this standard on a case-by-case basis.

The lack of a single standard leads to the existence of severa approaches to determining the standard of proof in arbitration. For example, a tribunal may use the principle of "balance of probabilities" (for example, this approach was applied in the case of Rompetrol v. Romania [4]), the principle of "most convincing evidence", which means that the arbitrator will decide in favour of the party whose statements are more likely to be true, and may apply a higher standard - the principle of "clear and convincing evidence" (the so-called "American standard"). This approach is recognized by a minority and is used quite rarely, however, it was used by ICSID in the case of Siag v. Egypt [5] with regard to Egypt's allegations of fraud. The most likely reason that this approach is not used often that it is quite difficult to prove corruption with a high extent of accuracy. Indeed, most often in this case, both parties (who gave and received the bribe) have reasons to hide the circumstances of this event. In addition, arbitration has no right to apply coercive measures. In light of the foregoing, obtaining direct evidence in international arbitration is extremely unlikely.

There is another interesting approach to proving corruption, namely the principle of "intime conviction" in other words, the arbitrator relies on his inner conviction. This approach was used by ICSID in the case of Metal-Tech v. Uzbekistan [6]. So, in January 2010, Metal-Tech filed a lawsuit with ICSID against Uzbekistan, believing that the decisions of the country's authorities led to the bankruptcy of Uzmetall Technology JV. When it became clear that some of the facts provided had no explanation, the arbitral tribunal asked the plaintiff to provide clarification on the contract for the provision of consulting services with a person who was closely associated with government officials. The plaintiff could not give any reasonable explanation about the need for the services of a consultant who did not have the appropriate qualifications related to the nature of the plaintiff's activities in Uzbekistan, or why the consultant was paid more than $\$$ 4 million to the account of an offshore Swiss company. In the case, the disturbing circumstances not substantiated by the plaintiff were obvious, and the arbitrators, due to the sufficiency of the circumstances, made an assumption about the fact of bribery. The case was closed on the basis of jurisdiction, the complaint of Metal-Tech, as well as the counterclaim of Uzbekistan were rejected.

The Metal-Tech decision is important for a number of reasons. First of all, the issue of corruption was raised by the arbitral tribunal on its own initiative (sua sponte), and was not announced by one of the parties. Secondly, the court exercised its right to demand that the participants in the process provide evidence and, having not received satisfactory explanations from the plaintiff, made unfavourable conclusions and decided on the fact of bribery.

The discrepancy between the various applicable standards of evidence set out above is clearly summarized in Tokelès v. Ukraine [7], which outlines three approaches to the standard of proof: (i) "the usual standard, which requires the plaintiff to convince the decision maker that his testimony is more like truth than untruth"; (ii) "if the dispute concerns a charge against a person or a body with high authority, the burden may be lower, simply because direct evidence is likely to be difficult to find"; and (iii) "the standard is higher than the balance of probabilities".

As mentioned above, in Metal-Tech v. Uzbekistan the issue of corruption was raised by the arbitration court on its own initiative (sua sponte). Sua sponte (lat. on their own initiative) - means the actions of a judge taken without the initiative of the parties to the dispute. Yes, the arbitrators are not the same as judges of state courts, but at the same time they have a duty to make enforceable decisions. Meanwhile, the ICSID Convention provides a mechanism for reviewing decisions, which means that the parties can seek a review or cancellation of the decision before the decision cancellation committee. To avoid this outcome, if one of the parties to the dispute claims corruption, or the arbitrators themselves suspect corruption, the arbitrators should consider investigating such facts (including sua sponte). Moreover, it does not matter at what stage of the arbitral proceedings such suspicions arose - even at the final stage, the arbitrators should conduct an investigation.

As part of the investigation, arbitrators may use different methods, excluding, of course, coercive methods. For example, an arbitrator may issue a procedural order to obtain additional 
oral or written information from the parties that could be useful in confirming or refuting allegations of corruption. As a general rule, in this situation, the parties should cooperate with the arbitration. Arbitrators may also ask one of the parties, mainly those who is accused of corruption, to provide evidence in defense of their position. However, the arbitrators always have the opportunity to ask both parties to provide evidence to confirm their position.

As we already found out, during the arbitration, both the party can state the fact of corruption, and the arbitrators themselves can suspect corruption. What signs may alert arbitrators? First of all, these are the so-called "red flags". In other words, some indicators of misconduct. In relation to arbitration, they are used not only as a means to identify facts of corruption, but also can subsequently be used as evidence. However, the concept of "red flags" [8] can be used not only in the context of international investment arbitration, but also in international commercial practice. So, many large organizations develop their own lists of red flags, for example, in order to subsequently be able to avoid unreliable contractors.

In the context of ICSID, according to scientists, the role of "red flags", among other things, can play:

the prevalence of corruption behaviour in the country, identified by certain international and non-governmental organizations, for example, the Corruption Perception Index, compiled by Transparency International;

criminal investigations were conducted prior to or during the local arbitration proceedings.

The company has already been held liable for such violations and does not provide any evidence that work was carried out to resolve this issue.

The company does not have a code of conduct or relevant certificates that ensure that the company fulfills its obligations to combat money laundering and to comply with regulatory requirements (compliance) (for example, indicating compliance with the provisions of the UK Bribery Act 2010, the US Foreign Corrupt Practices Act 1977 or the French Law on Combating Corruption, on Transparency and Modernization of Economic Life (Sapin II Act)).

The presence of at least a few of these principles should alert the arbitrators.

Of course, the "red flags" cannot be considered independent evidence of corruption. However, as indicators, they are part of circumstantial evidence and may subsequently lead to strong evidence.

If the fact of corruption is nevertheless proven, then the consequences for the parties to the dispute may vary depending on many factors, such as, for example, applicable law. Of course, the consequences in any case will be unpleasant for the parties - this may be the lack of jurisdiction of the arbitration, recognition of the claims of the parties as unacceptable or even their rejection due to corruption. An important role is also played by the following factor: when exactly, at which stage the fact of corruption took place. So, if the contract was originally concluded as a result of bribery, the question arises before the arbitrators: whether to recognize the absence of their jurisdiction in this matter, or recognize the claims as illegal? Without any doubts, such a decision is fraught with serious consequences for the investor, since in this case he is deprived of the right to demand protection of investments in accordance with international dispute resolution mechanisms.

However, realizing the above-mentioned circumstances, investors often try to avoid the continuation of the arbitration proceedings after the fact of corruption has been discovered.

For example, in the cases of Siemens v. Argentina (ICSID, 2007; court review and revocation proceedings were discontinued in 2009) [9] and Azpetrol v. Azerbaijan (ICSID, 2009) [10], the plaintiffs immediately settled the cases as soon as the fact of bribery was recognized. The settlement process was confidential.
Sometimes, in the event of the recognition of the inadmissibility of the claims, the arbitration applies the so-called "doctrine of unclean hands". This doctrine is quite interesting and suggests that a person involved in illegal activity, and committed bypass of the law, cannot judicially seek help after actions committed lawfully, but with the goal of covering another unlawful action. In this case, this means that the investor who initially concluded the contract through an act of corruption cannot claim protection of his interests under this contract, referring to an arbitration clause.

If it is proved that the investment contract was concluded legally, and the fact of corruption took place already in the investment process, the decision of the arbitration may be less grave for the investor. For example, an investor may lose protection only in that part of the investment that has been affected by corruption.

There is another extremely controversial aspect of this problem. Who should be more liable for corruption - the one who took the bribe or the one who gave it? This question is resolved by scientists in completely different ways: some authors propose that the investor who committed the act of corruption be held liable, their opponents say that the respondent state should also be liable either for prompting the applicant investor to commit a corrupt act or at least for its failure to investigate and prevent an act of corruption.

Recently, this topic has been widely discussed in scientific and practical circles. So, Sergey Alekhin and Leonid Shmatenko in their article give an interesting concept of "shield and sword" [11]. In their view, the fact of corruption has historically been considered by the respondent states as a "shield" against investor demands, while investors use the same argument as a "sword" against the respondent state. An investor may give different arguments to justify his position - whether it is extortion of bribes by an official of the respondent state or the commission by that state of illegal actions against the investor after receiving a bribe from a third party.

States can refer to corruption as a "shield" both at the jurisdictional and the merits phase. For example, in the African Holding Company v. Congo [12] case, defendants referred to allegations of corruption allegedly committed by plaintiffs to undermine the Tribunal's jurisdiction over the dispute.

On the other hand, in the case of Azpetrol v. Azerbaijan, it was the Plaintiffs' leading witness, who testified that the Plaintiffs bribed Azerbaijani officials. These confessions led to Azerbaijan's objection as to the admissibility of the claims on the grounds, that the investment was tainted by corruption and the applicants' behaviour violated international public policy.

From our point of view, the position that both sides should be liable for the fact of corruption is seen as correct. After all, when bribery is carried out, two parties are involved. A suitable example would be the World Duty Free case, which is criticized because the investor lost the opportunity to satisfy his claim because of the bribe, and the state was not punished. It is easy to imagine what consequences will come if an unclean state avoids liability every time. In that case, the state will have no incentive to provide the observation of domestic anticorruption legislation, to prosecute and punish its officials involved in corruption activities. Understanding this, now investment arbitration (in particular ICSID) pays attention to the behaviour of the state, referring to the fact of corruption. If the state does not make sufficient efforts to investigate this case and punish those involved in corruption, the arbitration tribunal will tend to reject the state's arguments that refers to corruption in an investment lawsuit. There are already examples (SPP v. Egypt [13] and WENA v. Egypt [14]) when a state's refusal to investigate or prosecute particular officials for possible corruption caused the arbitration to not take into account the arguments of the state's defense regarding corruption. 
Summing up, it should be noted that from the arbitration bodies, in addition to speed and fewer formalities during the settlement of disputes, maximum fairness is also required in relation to both parties. As a result of the research, it becomes clear that if suspicion of corruption arises in the case, they should not be ignored. In order to avoid infringement of the rights of one of the parties, such cases should be thoroughly investigated and both parties should bear liability. This will help stimulate both the investor and the state to comply with anti-corruption laws and to play fair games when concluding an investment contract. For the state, the fact that it cannot escape responsibility along with a dishonest investor will also become an incentive for improving its own anti-corruption legislation and practice in the investigation and prosecution of corrupt officials.

Fortunately, during the recent analysis of the ICSID practice, a positive trend has become noticeable - the distribution of responsibility between the investor and the state is becoming more balanced. This practice, combined with the improvement of the domestic anti-corruption legislation of individual states, will undoubtedly allow making arbitral awards much more balanced, reasonable and fair.

\section{REFERENCES}

1. World Duty Free Company Limited v. Republic of Kenya. Award (ICSID Case No. ARB / 00/7). International Centre for Settlement of Investment Disputes 2020. URL: https://icsid.worldbank.org/en/Pages/cases/casedetail.aspx?CaseNo=ARB/00/7 (Last accessed: 21.03.2020).

2. ICSID Convention. Award. International Centre for Settlement of Investment Disputes. 2020. URL: https://icsid.worldbank.org/en/ Documents/icsiddocs/ICSID\%20Convention\%20English.pdf (Last accessed: 21.03.2020).

3. ICSID Additional Facility Rules. Award. International Centre for Settlement of Investment Disputes. 2020. URL: https://icsid.worldbank. org/en/Documents/icsiddocs/AFR_English-final.pdf (Last accessed: 21.03.2020).

4. Rompetrol Group N.V. v. Romania. Award (ICSID Case No. ARB / 06/3). International Centre for Settlement of Investment Disputes. 2020. URL: https://icsid.worldbank.org/en/Pages/cases/casedetail.aspx?CaseNo=ARB/06/3 (Last accessed: 21.03.2020).

5. Siag v. Egypt. Award (ICSID Case No. ARB / 05/15). International Centre for Settlement of Investment Disputes. 2020. URL: https:/icsid. worldbank.org/en/Pages/cases/casedetail.aspx?CaseNo=ARB/05/15 (Last accessed: 21.03.2020).

6. Metal-Tech Ltd. v. Republic of Uzbekistan. Award (ICSID Case No. ARB / 10/3). International Centre for Settlement of Investment Disputes. 2020. URL: https://icsid.worldbank.org/en/Pages/cases/casedetail.aspx?CaseNo=ARB/10/3 (Last accessed: 21.03.2020).

7. Tokios Tokelès v. Ukraine. Award (ICSID Case No. ARB / 02/18). International Centre for Settlement of Investment Disputes. 2020. URL: https://icsid.worldbank.org/en/Pages/cases/casedetail.aspx?CaseNo=ARB/02/18 (Last accessed: 21.03.2020).

8. Basel Institute on Governance 2019, Corruption and Money Laundering in International Arbitration: a toolkit for Arbitrators. URL: https://www.baselgovernance.org/sites/default/files/2019-05/a toolkit for arbitrators 29052019 single pages.pdf (Last accessed: 21.03.2020).

9. Siemens A.G. v. Argentine Republic. Award (ICSID No. ARB / $\overline{0} 2 / 8)$. International Centre for Settlement of Investment Disputes. 2020. URL: https://icsid.worldbank.org/en/Pages/cases/casedetail.aspx?CaseNo=ARB/02/8 (Last accessed: 21.03.2020).

10. Azpetrol v. Azerbaijan. Award (ICSID No. ARB/06/15). International Centre for Settlement of Investment Disputes. 2020. URL: https://icsid.worldbank.org/en/Pages/cases/casedetail.aspx?CaseNo=ARB/06/15 (Last accessed: 21.03.2020).

11. Corruption in Investor-State Arbitration - It Takes Two to Tango. New Horizons of International Arbitration. Moscow, 2018. Collection of Articles, issue 4. Pp. 150-179.

12. African Holding Company v. Congo. Award (ICSID No. ARB/05/21). International Centre for Settlement of Investment Disputes. 2020. URL: https://icsid.worldbank.org/en/Pages/cases/casedetail.aspx?CaseNo=ARB/05/21 (Last accessed: 21.03.2020).

13. SPP v. Egypt. Award (ICSID No. ARB/84/3). International Centre for Settlement of Investment Disputes. 2020. URL: https://icsid.worldbank.org/en/Pages/cases/casedetail.aspx?CaseNo=ARB/84/3 (Last accessed: 21.03.2020).

14. Wena Hotels Limited v. Arab Republic of Egypt. Award (ICSID No. ARB / 98/4). International Centre for Settlement of Investment Disputes. 2020. URL: https://icsid.worldbank.org/en/Pages/cases/casedetail.aspx?CaseNo=ARB/98/4 (Last accessed:: 21.03.2020).

15. Schreuer H. Christoph. The ICSID Convention. A Commentary. Cambridge, the United Kingdom : Camridge University Press, 2001. 